\title{
Estrus Synchronization and Artificial Insemination with Fresh and Chilled Semen in Assaf Ewes
}

\author{
Raquel Fornazari1 ${ }^{1}$ Óscar Mateus ${ }^{2}$, Teresa Correia ${ }^{2,3}$, Hélder Quintas²,3, Raimundo Maurício², \\ Anderclei Conradi', Lucas Francisco' ${ }^{1}$, Armindo Álvaro4, Ramiro Valentim²,3
}

${ }^{1}$ Federal Technology University of Paraná, Campus of Dois Vizinhos, Dois Vizinhos, Brasil

${ }^{2}$ Department of Animal Science, Agrarian Superior School of Braganza, Braganza, Portugal

${ }^{3}$ Mountain Investigation Center, Polytechnic Institute of Braganza, Braganza, Portugal

${ }^{4}$ Polytechnic Superior Institute of Kwanza Sul, Sumbe, Angola

Email: valentim@ipb.pt

How to cite this paper: Fornazari, R., Mateus, Ó., Correia, T., Quintas, H., Maurício, R., Conradi, A., Francisco, L., Álvaro, A. and Valentim, R. (2018) Estrus Synchronization and Artificial Insemination with Fresh and Chilled Semen in Assaf Ewes. Agricultural Sciences, 9, 8-22.

https://doi.org/10.4236/as.2018.91002

Received: November 29, 2017

Accepted: January 6, 2018

Published: January 9, 2018

Copyright $(9) 2018$ by authors and Scientific Research Publishing Inc. This work is licensed under the Creative Commons Attribution International License (CC BY 4.0).

http://creativecommons.org/licenses/by/4.0/

\begin{abstract}
This paper aims to study the efficiency of two short-term progestagen (FGA vs. MAP) + eCG treatments in estrus synchronization and artificial insemination (AI) with fresh or chilled semen in Assaf ewes fertility rate. All ewes received a subcutaneous implant of exogenous melatonin 45 days before been treated with short-term progestagens + eCG. By June $1^{\text {st }}$, ewes were divided in two groups: half was treated with an intravaginal sponge impregnated with 20 mg of FGA and the other half with an intravaginal sponge impregnated with $60 \mathrm{mg}$ of MAP. Progestagen treatments lasted for 6 days. At sponge withdraw, all ewes were injected with $750 \mathrm{IU}$ of eCG. Ovarian activity was assessed by plasmatic progesterone levels before and after progestagens + eCG treatment. Semen was collected by electro ejaculation and extended with Andromed or OviXcell. . AI was performed 55 hours after eCG administration with fresh or chilled semen. During AI several factors were assessed: vagina mucosa color and lubrication, external cervical $O s$ type, cervical mucous viscosity, semen deposition place and seminal cervix outflow. Semen was deposited as deep as possible without distress or trauma cervix mucosa. All Assaf ewes presented cyclic activity before progestagen + eCG treatments ( $2^{\text {nd }}$ fortnight of May). Short-term progestagen + eCG treatments were equally efficient (100.0\%). About $76.5 \%$ of Assaf ewes were pregnant 41 days after AI. Fertility rate was influenced by external $O s$ type, semen deposition place and seminal cervix outflow. However, this rate was not conditioned by vaginal color or lubrication, cervical mucus viscosity, semen preservation technic and semen extender.
\end{abstract}




\section{Keywords}

Sheep, Assaf, Estrus Synchronization, Artificial Insemination

\section{Introduction}

Reproduction control and AI hold several advantages to commercial flocks: they improve farm management [1] [2] [3] and production [4]-[9], reproduction data recording accuracy [4] [7], genetic progress and animals production value [4] [5] [6] [7] [10]-[19] and allow the use of temporary physic, physiology or behavior defective animals as breeders [7] [14], precocious detection of infertility or subfertility [5] [20], control sexual transmitted diseases [4] [6] [9] [10] [14] [15] [21] and improve profitability [4] [6] [7] [22]. Nevertheless this technic is scarcely used in the Northeast of Portugal due to breeders' age, poor education, size and scarce property ownership, tradition, among other factors.

\section{Material and Methods}

This study took place in Carviçais, Torre de Moncorvo County (Portugal), at the Mateus Lda. commercial farm (Latitude: $41^{\circ} 10^{\prime} \mathrm{N}$, Longitude: $6^{\circ} 55^{\prime} \mathrm{W}$ and Altitude: 701 meters) between April $1^{\text {st }}$ and July $20^{\text {th }}, 2017$.

Ewes were permanently raised indoors, fed in group with natural meadow hay (ad libitum) and supplemented with $1.0 \mathrm{~kg} / \mathrm{ewe} /$ day of Lucerne hay and 1.0 $\mathrm{kg} /$ ewe/day of a commercial food product. During the milking process, twice a day, ewes were individually supplemented with $0.5 \mathrm{~kg}$ of a commercial food product.

Ewes were weighted in a cage scale and the body score was classified according to the Australian Body Score Condition (BSC) table [23].

\subsection{Animals}

Thirty-four ewes (primiparous: 33 and multiparous: 1 ) and two adult ( $2-3$ years old) Assaf rams were used in this study. Last lambing happened 3 - 4 months earlier. All ewes were milked twice a day.

\subsection{Ovarian Activity}

Ovarian activity was assessed by plasmatic progesterone levels. Blood samples were collected to vacuum tubes with heparin by jugular vein puncture. After blood centrifugation at 3,000 rpm, for 15 minutes, at room temperature, blood plasma was collected to previously identified Eppendorf tubes and briefly preserved in an ultra-freezer at $-70^{\circ} \mathrm{C}$. RIA assessed Progesterone plasmatic levels using a DPC ${ }^{\circ}$ Gamma C12 scintillation counter and DiaSource kits (DiaSource ImmunoAssays S.A., Louvain-la-Neuve, Belgium). Intra and inter assays mean coefficients were $7.7 \%$ and $15.8 \%$, respectively. 
Only ejaculates with volume higher than $1.0 \mathrm{ml}$, good wave motility and a minimum concentration of $3.0 \times 10^{9}$ spermatozoa $/ \mathrm{ml}$ were used. Each seminal dose was prepared to contain at least $200 \times 10^{6}$ spermatozoa.

\subsection{Semen Doses}

Morning collected ejaculates from the same male were well mixed before been divided into two tubes and extended (1:1) with Andromed (Minitüb, Tiefenbach, Deutschland) or OviXcell' (IMV Technologies, L'Aigle, France). Ten minutes later extended semen was cooled from $37^{\circ} \mathrm{C}$ to $15^{\circ} \mathrm{C}$, for 120 minutes, in a refrigerator water-bath (Neslab ${ }^{\circ}$ RTE 221, Newington, USA). After been stabilized for 10 minutes, extended semen was packed in $0.25 \mathrm{ml}$ French mini straws and sealed with polyvinyl chloride powder.

Afternoon collected ejaculates from the same male were well mixed before been divided into two tubes and extended (1:1) with Andromed (Minitüb, Tiefenbach, Deutschland) or OviXcell (IMV Technologies, L'Aigle, France). After been stabilized for 10 minutes at $37^{\circ} \mathrm{C}$, extended semen was packed into $0.25 \mathrm{ml}$ French mini straws and sealed with polyvinyl chloride powder. AI started less than 30 minutes later.

\subsection{Time Fixed Artificial Insemination}

AI started 55 hours after eCG administration. Ewes began to be inseminated with fresh extended semen. One skilled technician performed AI.

Near half ewes treated with FGA + eCG were inseminated with fresh diluted semen and the other half with chilled semen. The same was done in ewes treated with MAP + eCG. Within both groups some ewes were inseminated with semen extended with Andromed and the others with semen extended with OviXcell (Table 2).

During AI the following factors were assessed: vagina mucosa color (Pale pink vs. Pink vs. Dark pink), vagina lubrication (Good vs. Poor), external cervical $O s$ type (Figure 1), cervical mucus viscosity (Liquid vs. Viscose), semen deposition place (Vaginal vs. $1^{\text {st }}$ fold vs. $2^{\text {nd }}$ fold) and seminal cervical outflow (No outflow vs. Light outflow vs. Plentiful outflow).

Semen was preferentially placed as deep as possible in the cervical canal, but

Table 2. Fresh or chilled semen doses extended with Andromed ${ }^{\circ}$ or OviXcell ${ }^{\circ}$ used to AI treated ewes.

\begin{tabular}{|c|c|c|c|c|c|c|c|}
\hline \multicolumn{8}{|c|}{ Assaf Ewes $(n=34)$} \\
\hline \multicolumn{4}{|c|}{$\begin{array}{c}\text { FGA + eCG } \\
\quad(\mathrm{n}=17)\end{array}$} & \multicolumn{4}{|c|}{$\begin{array}{c}\text { MAP + eCG } \\
(\mathrm{n}=17)\end{array}$} \\
\hline \multicolumn{2}{|c|}{$\begin{array}{l}\text { Fresh } \\
(\mathrm{n}=8)\end{array}$} & \multicolumn{2}{|c|}{$\begin{array}{l}\text { Chilled } \\
(\mathrm{n}=9)\end{array}$} & \multicolumn{2}{|c|}{$\begin{array}{l}\text { Fresh } \\
(\mathrm{n}=8)\end{array}$} & \multicolumn{2}{|c|}{$\begin{array}{l}\text { Chilled } \\
(\mathrm{n}=9)\end{array}$} \\
\hline $\begin{array}{l}\text { Andromed } \\
\quad(\mathrm{n}=3)\end{array}$ & $\begin{array}{c}\text { OviXcell } \\
(\mathrm{n}=5)\end{array}$ & $\begin{array}{l}\text { Andromed } \\
\quad(\mathrm{n}=6)\end{array}$ & $\begin{array}{c}\text { OviXcell } \\
(\mathrm{n}=3)\end{array}$ & $\begin{array}{l}\text { Andromed } \\
\quad(\mathrm{n}=6)\end{array}$ & $\begin{array}{l}\text { OviXcell } \\
(\mathrm{n}=2)\end{array}$ & $\begin{array}{l}\text { Andromed } \\
\quad(\mathrm{n}=3)\end{array}$ & $\begin{array}{c}\text { OviXcell } \\
(\mathrm{n}=6)\end{array}$ \\
\hline
\end{tabular}




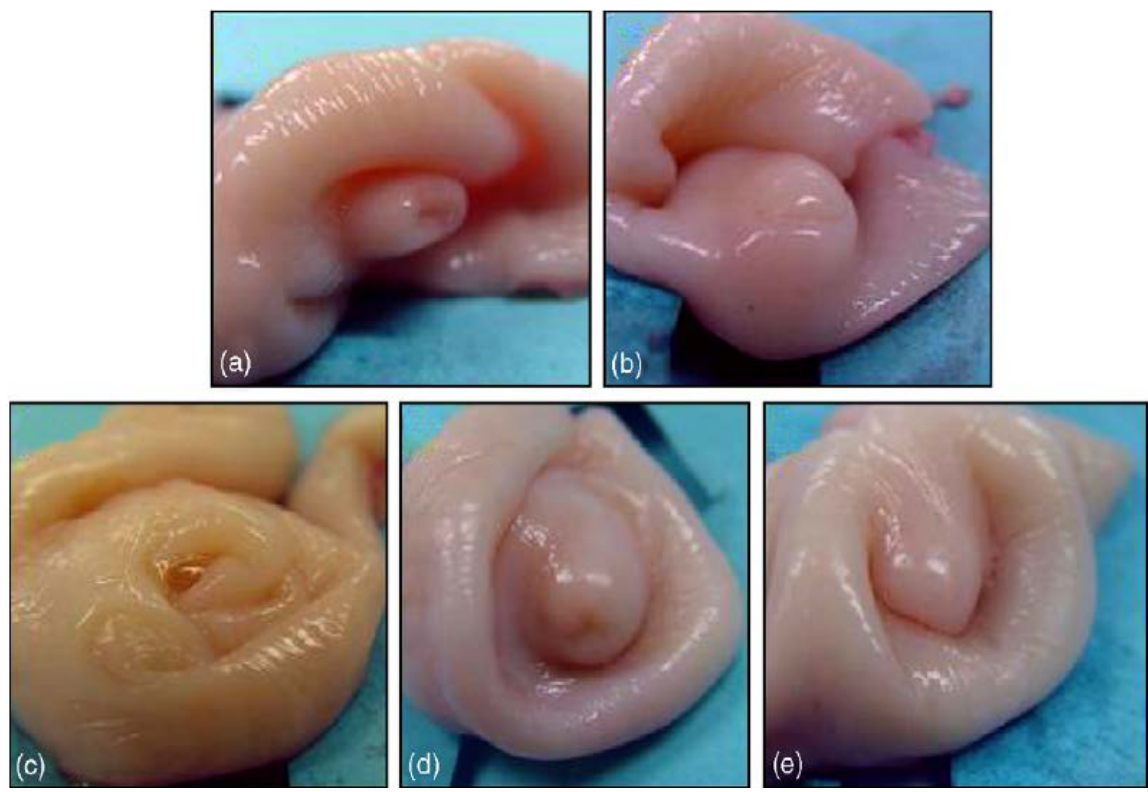

Figure 1. External cervical Os types: (a) Duckbill; (b) Slit; (c) Rose; (d) Papilla; and (e) Flap [25].

avoiding distress or trauma the mucosa. AI was performed using a vaginal speculum fitted with a white LED light and Quicklock guns covered with a Minitub sheath (Minitüb, Tiefenbach, Deutschland).

\subsection{Pregnancy Diagnosis}

Forty-one days (20/07/17) after AI (09/06/17) pregnancy diagnosis were conducted by real-time ultrasonography, using a Mindray Z5Vet ultra-sounder and a multi-frequency rectal probe $(5.0-10.0 \mathrm{MHz})$.

\subsection{Statistical Analysis}

Descriptive statistics are presented as mean \pm standard deviation (coefficient of variation-c.v.). Data were statistically analyzed according to the ANOVA [26] and BonferronilDunn test [27] to detect difference between means. Distributions of external Os types were analyzed using the Chi-square $\left(\chi^{2}\right)$ test [28]. All statistical analyses were performed using SAS Statistical Software, version 9.2 [29].

\section{Results and Discussion}

Assaf ewes were quite young - $2.0 \pm 0.3$ years old (c.v. $=15.2 \%$ ). Age difference between FGA and MAP treated groups, inseminated with diverse semen extenders (Andromed ${ }^{\circ}$ vs. OviXcell ${ }^{\circ}$ ), after semen preservation with unlike technics (Fresh vs. Chilled) was not significant $(\mathrm{P}>0.05)$ (Table 3$)$. These results are probably related to age homogeneity of all ewes.

Ewes weighted $69.4 \pm 11.2 \mathrm{~kg}(\mathrm{c} . \mathrm{v} .=16.1 \%)$ and presented a BSC of $3.5 \pm 0.5$ points $($ c.v. $=13.3 \%)$. Weight and BSC differences between FGA and MAP 
Table 3. Mean age, body weight and body score condition (BSC) of Assaf ewes by hormonal treatment, semen extender and preservation technique.

\begin{tabular}{cccc}
\hline & Age (years) & Weight (kg) & BSC (points) \\
FGA & $1.9^{\mathrm{a}} \pm 0.4$ & $68.9^{\mathrm{a}} \pm 11.0$ & $3.5^{\mathrm{a}} \pm 0.5$ \\
MAP & $2.0^{\mathrm{a}} \pm 0.0$ & $69.9^{\mathrm{a}} \pm 11.7$ & $3.5^{\mathrm{a}} \pm 0.4$ \\
Andromed & $1.9^{\mathrm{a}} \pm 0.4$ & $66.9^{\mathrm{a}} \pm 12.3$ & $3.4^{\mathrm{a}} \pm 0.5$ \\
OviXcell $^{\circ}$ & $2.0^{\mathrm{a}} \pm 0.0$ & $72.1^{\mathrm{a}} \pm 9.5$ & $3.5^{\mathrm{a}} \pm 0.4$ \\
Fresh & $2.0^{\mathrm{a}} \pm 0.4$ & $72.4^{\mathrm{a}} \pm 13.6$ & $3.7^{\mathrm{a}} \pm 0.5$ \\
Chilled & $1.9^{\mathrm{a}} \pm 0.2$ & $66,9^{\mathrm{a}} \pm 8.2$ & $3.3^{\mathrm{a}} \pm 0.4$ \\
\hline
\end{tabular}

$\mathrm{a}=\mathrm{a}$, for $\mathrm{P}>0.05$ (between lines).

treated groups, semen extenders groups and preservation technics groups were not significant $(\mathrm{P}>0.05)$. Assaf ewes presented a body weight and BSC suitable to breeding activity, regardless been at the $3-4^{\text {th }}$ month of lactation. O'Brian [30], Scaramuzzi and Martin [31] and Karikariand and Blasu [32] says ewes should be bred with a BSC ranging between $2.5-3.0$ points.

\subsection{Physiological State Previous to Short-Term Progestagen Treatments}

Before starting a reproduction control and AI program researchers should always check for ewes' ovarian activity [33]. At the second fortnight of May all ewes $(\mathrm{n}=34)$ presented plasmatic levels of progesterone higher than $0.5 \mathrm{ng} / \mathrm{ml}$, meaning they were cycling $(100.0 \%)$. This outcome may reflect the pre-treatment of all ewes with melatonin implants or simply be the result of warmer environmental temperatures (late spring), more suitable to thermoregulation and consequently to reproduction activity [34] [35] [36] [37].

Age, body weight and BSC had no significant effect in the physiological state prior to short-term progestagen treatments + eCG $(\mathrm{P}>0.05)$.

\subsection{Ovarian Response to Short-Term Progestagen Treatments}

Both short-term progestagen treatments + eCG were 100.0\% efficient. Highly favorable body weight and BSC, warm environmental temperatures and prior ovarian cyclicity may have determined this result.

Progesterone plasmatic levels rose above $0.5 \mathrm{ng} / \mathrm{ml}$ for the first time around $28.9 \pm 11.5$ hours (c.v. $=39.7 \%)$ after eCG administration. Ovulatory response was rather fast, maybe due to the administration of $750 \mathrm{IU} /$ ewe. eCG has been shown to reduce the interval between sponge withdrawal and estrus and improve the efficiency of synchronization of estrus and ovulation during the breeding season [38]. However, fertility rate tends to be maximum when AI is performed at the second half of the estrous, a few hours before ovulation [39].

Progestagens treatment (FGA-28.3 \pm 12.7 hours vs. MAP-29.6 \pm 10.5 hours) had no significant influence in this parameter $(\mathrm{P}>0.05)$. In small rumi- 
nants, FGA has a shorter half-life than MAP [40]. FGA induces an earlier return to ovarian cyclic activity (higher precision) than MAP, although, with no significant effect in estrus length [41]. Treatment with MAP sponges does not adequately synchronize estrus and ovulation among cyclic ewes [41]. However, Abecia et al. [2], Ungerfeld e Rubianes [42], Zeleke et al. [43], Mateus [44], Afonso [45] and Dendena [46] were not able to establish any synchronization efficiency difference between FGA and MAP treatments. Present results meet these last investigators' observations. Exogenous gonadotropin administration does advance ovulation and higher estrous synchronization precision [1] [9] [47]. They support ovarian mechanisms affecting follicular growth and maturation and promoting the proper luteinization of the CL [4] [9] [40].

The interval between synchronization treatment and AI is very important [48]. Different investigators propose unlike intervals: 46 hours (Fernandez-Abella et al., 2003; cited by [48]), 48 - 72 hours (Karagiannidis et al., 2001; cited by [48]), 55 hours [46] [49] and 58 - 63 hours [50] [51]. The decision to inseminate 55 hours post eCG administration originated a reasonable fertility rate.

\subsection{Artificial Insemination Response}

About $76.5 \%$ of all Assaf ewes were pregnant 41 days after AI. This result was higher than many indicated in the bibliography for sheep: 50\% - 65\% [4] [49] [52], 65\% - 75\% (Colas and Guérin 1979; cited by [53]), although Assaf ewes were mainly primiparous and the short interval between progestagens sponge removal and first CL formation. Ewes tend to present estrus 36 hours after progestagens sponge removal [5] and to ovulate in 58 - 60 hours [33]. Other investigators report higher fertility rates 70\% - 82\% [50] [51], 82.2\% (Hill et al., 1998 and Ehling et al., 2003; cited by [48]), 85.1\% [46] and 80\% - 90\% [48].

\subsection{1. eCG}

Fertility rate after AI depends on eCG dose [Hill et al., 1998; cited by 47]: 200 IU-62.4\%, $250 \mathrm{IU}-72.9 \%, 300 \mathrm{IU}-79.1 \%$ and $375 \mathrm{IU}->69.4 \%$. Dendena [46] stated a fertility rate of $85.1 \%$ after the administration of 500 IU of eCG. In the present paper, the administration of 750 IU of eCG determined a fertility rate of 76.5\%. Racial differences may partially explain the results [5] [12] [54]. Less prolific and less seasonal breeds tend to be more responsive to eCG administration [4] [53]. Different follicular populations present on the ovaries before progestagen treatments + eCG may also condition fertility rate [41] [54].

\subsubsection{Semen Preservation Technic}

Fertility rates tend to be smaller after AI with chilled semen than with fresh semen [5] [55] - 56.7\% (Fernandez-Abella et al., 2003; cited by [48]) or $74 \%-76 \%$ (Gergátz and Gyökér, 1997; cited by [48]). Dendena [45] found exactly the opposite (Fresh: $79.4 \%$ vs. Chilled: $90.9 \%$ ). During semen chilling the sperm cells lose motility, suffer morphological changes and decay survive ability in the female genital tract, resulting in lower fertility rates and higher embryonic mortal- 
ity [56] [57]. In the present work, fertility rate was not conditioned by semen preservation technic (Fresh: $81.3 \%$ vs. Chilled: $72.2 \%)\left(\chi^{2}=2.3 ; \mathrm{P}>0.05\right)$.

\subsubsection{Semen Extender}

Semen extenders are expected to increase extended semen volume, stabilize $\mathrm{pH}$ (buffer effect), keep adequate osmolality, provide energy to spermatozoa and protect them from possible bacteria and fungus infections, cold shock and preservation process [4] [5] [9] [11] [12] [58]-[63] resulting in osmotic stress and reactive oxygen species (ROS) [57] [60].

Semen extender did not affect fertility rate (Andromed ${ }^{\circ}: 77.8 \%$ vs. OviXcell: 75.0\%) $\left(\chi^{2}=0.3 ; \mathrm{P}>0.05\right)$. Though Andromed ${ }^{\circ}$ was developed to preserve bull semen and OviXcell to preserve ram semen their effects on fertility rate were identical. Dendena [46] also found no significant difference between semen extenders (Andromed vs. INRA 96 ) in fertility rate.

\subsubsection{Color and Lubrication of Vagina and Cervical Viscosity}

In cervical AI, semen is usually placed in the anterior portion of the cervix [63]. So, semen transportation through the cervical canal depends on cervical mucus volume and quality [64]. All Assaf ewes presented a Pink vaginal mucosa and a Good lubrication (100.0\%). Cervical mucus has Liquid in all ewes (100.0\%). These results are possibly related to short-term progestagens + eCG treatments and to the time of AI and reveals that ewes were well-fed, healthy and in an advanced stage of the follicular phase or early stage of the luteal phase. Dendena [46] reported that the majority of Churra Galega Bragançana Branca ewes presented a Pink color and highly lubricated vagina.

\subsubsection{Cervical External Os}

Assaf ewes presented all types of external $O s$ in [24] classification table (Table 4). The same was found by [46] in Churra Galega Bragançana Branca ewes. Os types frequency variation was significant $\left(\chi^{2}=13.8\right.$; $\left.\mathrm{P} \leq 0.01\right)$. Nevertheless frequency distribution was uniform, but for Slit type (less frequent). Frequency distribution registered by [46] was quite different and may be due to genetics, age and parity factors [24] [54].

Table 4. Anatomical conformation of the cervical external $O s$ (frequency) and its relation to fertility rate.

\begin{tabular}{|c|c|c|}
\hline External $O s$ & Frequency & Fertility rate \\
\hline Duckbill & $20.6 \%^{\mathrm{a}}(7 / 34)$ & $85.7 \%^{x}(6 / 7)$ \\
\hline Slit & $8.8 \%^{\mathrm{b}}(3 / 34)$ & $33.3 \%^{\mathrm{y}}(1 / 3)$ \\
\hline Rose & $29.4 \%^{\mathrm{a}, c, e}(10 / 34)$ & $80.0 \%^{\mathbf{z , x}}(8 / 10)$ \\
\hline Papilla & $23.5 \% \%^{\mathrm{a}, \mathrm{d}, \mathrm{e}}(6 / 34)$ & $100.0 \%^{\mathrm{w}, \mathrm{z}, \mathrm{v}}(6 / 8)$ \\
\hline Flap & $17.6 \% \%^{\mathrm{a}, \mathrm{b}, \mathrm{f}}(5 / 34)$ & $88.9 \%^{\mathrm{v}, \mathrm{x}, \mathrm{y}, \mathrm{w}}(5 / 6)$ \\
\hline
\end{tabular}

$a \neq b$, for $P \leq 0.05 ; b \neq d$, for $P \leq 0.01 ; b \neq c$, for $P \leq 0.001 ; x \neq w$, for $P \leq 0.05 ; x \neq y, y \neq z, y \neq w, y \neq v$, for $P$ $\leq 0.001$ (between lines). 
External Os type influenced fertility rate $\left(\chi^{2}=93.5 ; \mathrm{P}<0.001\right)$ (Table 4). The same was registered by [45]. Pappila (100.0\%), Flap (88.9\%), Duckbill (85.7\%) and Rose $(80.0 \%)$ types were related to high fertility rates. On the opposite, Slit type was related to the lowest fertility rate. Dendena [46] found the highest fertility rates among ewes with Papilla and Slit types of the external $O s$.

\subsubsection{Semen Deposition Place}

Fertility rate is higher when semen is placed deeper in the cervix during cervical insemination [3] [65]. Spanish sheep breeds with low fertility rate (Assaf and Churra) present a more complex cervical canal, which impairs deep penetration [65]. Cervix distress or trauma may condition fertility rate by affecting semen transport and viability in the female genital tract, originated by an influx of immune cells to the cervical canal [7] [13] [66]. In the present study, semen was mainly placed after the first cervical fold (Table 5). Dendena [46] reported the same. Fertility rate was quite high $(78.8 \%)$. The only vaginal inseminated ewe did not get pregnant $(0.0 \%)$. This author found the same rate of fertility in Churra Galega Bragançana Branca ewes when semen was left in the vagina or after the first cervical fold (Vagina: $88.9 \%$ vs. $1^{\circ}: 88.2 \%$ ).

\subsubsection{Cervical Outflow}

Low fertility rates are related to semen cervical outflow in sheep [13] [14]. Cervical outflow should be avoided [15] [46], especially when it is plentiful [46]. In the present work, most ewes inseminated after the first fold did not present any cervical outflow (Table 6) and resulted in a high fertility rate $(81.5 \%)$. Ewes with a light outflow presented a lower fertility rate $(66.7 \%)\left(\chi^{2}=81.9 ; \mathrm{P}<0.001\right)$.

\section{Conclusions}

- On the second fortnight of May, Assaf ewes were all cycling.

- Both short-term progestagens (FGA e MAP) + eCG were 100.0\% efficient.

- FGA and MAP showed equal precision controlling first CL formation (FGA $28.3 \pm 12.7$ days vs. MAP $-29.6 \pm 10.5$ days.

Table 5. Semen deposition place (frequency) and fertility rate.

\begin{tabular}{ccc}
\hline Semen deposition place & Frequency & Fertility rate \\
\hline Vagina & $2.9 \%^{\mathrm{a}}(1 / 34)$ & $0.0 \%^{\mathrm{x}}(0 / 1)$ \\
$1^{\text {st }}$ fold & $97.1 \%^{\mathrm{b}}(33 / 34)$ & $78.8 \%^{\mathrm{y}}(26 / 33)$ \\
\hline
\end{tabular}

$\mathrm{a} \neq \mathrm{b}$ for $\mathrm{P} \leq 0.0001 ; \mathrm{x} \neq \mathrm{y}$ for $\mathrm{P} \leq 0.001$ (between lines).

Table 6. Cervical outflow (frequency) and fertility rate.

\begin{tabular}{ccc}
\hline Cervical outflow & Frequency & Fertility rate \\
\hline No & $27 / 33\left(81.8 \%^{\mathrm{a}}\right)$ & $22 / 27\left(81.5 \%^{\mathrm{x}}\right)$ \\
Light & $6 / 33\left(18.2 \%^{\mathrm{b}}\right)$ & $4 / 6\left(66.7 \%^{\mathrm{y}}\right)$ \\
\hline
\end{tabular}

$\mathrm{a} \neq \mathrm{b}$, for $\mathrm{P} \leq 0.0001 ; \mathrm{x} \neq \mathrm{y}$ for $\mathrm{P} \leq 0.05$ (between lines). 
- Forty-one days after AI 76.5\% of the Assaf ewes were pregnant.

- Fertility rate was significantly affected by external $O s$ type, semen deposition place (Vagina: $0.0 \%$ vs. $1^{\circ}: 78.8 \%$ ) and seminal cervix outflow (No outflow: $81.5 \%$ vs. Light outflow: $66.7 \%)$.

- Fertility rate was not significantly influenced by vagina color (Pink: $100.0 \%$ ) and cervical mucus viscosity (Liquid: 100\%), semen extender (Andromed: $77.8 \%$ vs. OviXcell: $75.0 \%$ ) or semen preservation technic (Fresh: $81.3 \%$ vs. Chilled: $72.2 \%)$.

\section{Animal Rights}

This experiment comply with the ARRIVE guidelines and have be carried out in accordance with the U.K. Animals (Scientific Procedures) Act, 1986 and associated guidelines, EU Directive 2010/63/EU for animal experiments.

\section{Conflict of Interest}

The authors declare that they have no conflict of interest.

\section{Acknowledgments}

The authors wish to thank Dra. Angelita Walker Duarte for her help in the English review of this paper.

\section{References}

[1] Azevedo, J.M., Valentim, R.C. and Correia, T.M. (2006) Hormonal Control of Sheep Ovarian Activity [Controlo Hormonal da Actividade Ovárica em Ovinos]. Albéitar Portuguesa, 2, 4-8.

https://bibliotecadigital.ipb.pt/bitstream/10198/6302/1/Albeitar\%20Control\%20Act \%200v\%C3\%A1rica\%206\%20\%282006\%29.pdf

[2] Abecia, J.A., Forcada, F. and González-Bulnes, A. (2012) Hormonal Control of Reproduction in Small Ruminants. Animal Reproduction Science, 130, 173-179. https://doi.org/10.1016/j.anireprosci.2012.01.011

[3] Valentim, R., Rodrigues, I., Montenegro, T., Sacoto, S. and Azevedo, J. (2015) Reproduction Management in Sheep and Goat. 4. Breeding Activity Control in Small Ruminants-Natural Methods [Maneio Reprodutivo em Ovinos e Caprinos. 4. Controlo da Atividade Reprodutiva em Pequenos Ruminantes-Métodos Naturais]. Agrotec, 17, 19-23.

https://www.researchgate.net/publication/282327460_Maneio_reprodutivo_em_ovi nos_e_caprinos_4_Controlo_da_atividade_reprodutiva_em_pequenos_ruminantes --_metodos_naturais

[4] Baril, G., Chemineau, P., Cognié, Y., Guérin, Y., Leboeuf, B., Orgeur, P. and Vallet, J.-C. (1993) Manuel de Formation pour L'insémination Artificielle chez les Ovins et les Caprins. Étude FAO Production et Santé Animales, Rome. http://www.fao.org/docrep/009/t0121f/t0121f00.htm

[5] Gordon, I. (1997) Controlled Reproduction in Sheep and Goats. CABI Publishing University Press, Cambridge.

[6] Leboeuf, B., Restall, B. and Salamon, S. (2000) Production and Storage of Goat Se- 
men for Artificial Insemination. Animal Reproduction Science, 62, 113-141. https://doi.org/10.1016/S0378-4320(00)00156-1

[7] Aisen, E.G. (2004a) Processing and Conservation of Semen [Procesamiento y Conservación del Material Seminal]. In: Aisen, E.G., Ed., Reproducción Ovina y Caprina, Chapter 6, Intermédica Editora, São Paulo, 73-86.

[8] Granados, L.B.C., Dias, A.J.B. and Sales, M.P. (2006) General Issues in Goat and Sheep Reproduction [Aspectos Gerais da Reprodução de Caprinos e Ovinos]. State University of North Fluminense Darcy Ribeiro, Rio de Janeiro.

[9] Valentim, R., Rodrigues, I., Montenegro, T., Sacoto, S., Azevedo, J. and Gomes, M.J. (2016a) Reproduction Management in Sheep and Goat. 7. Artificial Insemination in Sheep and Goat [Maneio Reprodutivo em Ovinos e Caprinos. 7. Inseminação Artificial em Ovinos e Caprinos]. Agrotec, 21, 10-13.

https://www.researchgate.net/publication/307571147_Maneio_Reprodutivo_em_Ov inos_e_Caprinos_7_Inseminacao_Artificial_em_Ovinos_e_Caprinos

[10] Chemineau, P., Malpaux, B., Pelletier, J., Lebouf, B., Delgadillo, J.A., Deletang, F., Pobel, T. and Brice, G. (1996) Emploi des Implants de Mélatonine et des Traitements Photopériodiques pour Maîtriser la Reproduction Saisonnière chez les Ovins et les Caprins. INRA Productions Animales, 9, 45-60. http://prodinra.inra.fr/record/125116

[11] Aisen, E.G.M (2004b) Artificial Insemination in Ewe and Goat [Inseminación Artificial de Ovejas y Cabras]. In: Aisen, E.G., Ed., Reproducción Ovina y Caprina, Chapter 8, Intermédica Editora, São Paulo, Brazil, 99-114.

[12] Anel, L., Alvarez, M., Martinez-Pastor, F., Garcia-Macias, V., Anel, E. and de Paz, P. (2006) Improvement Strategies in Ovine Artificial Insemination. Reproduction in Domestic Animals, 41, 30-42.

[13] Candappa, I.B.R. and Bartlewski, P.M. (2011) A Review of Advances in Artificial Insemination (AI) and Embryo Transfer (ET) in Sheep, with the Special Reference to Hormonal Induction of Cervical Dilation and its Implications for Controlled Animal Reproduction and Surgical Techniques. The Open Reproductive Science Journal, 3, 162-175. https://doi.org/10.2174/1874255601103010162

[14] Morrell, J.M. (2011) Artificial Insemination: Current and Future Trends. In: Manafi, M., Ed., Artificial Insemination in Farm Animals, Chapter 1, InTech, Rijeka, 1-14.

[15] Cseh, S., Faigl, V. and Amiridis, G.S. (2012) Semen Processing and Artificial Insemination in Health Management of Small Ruminants. Animal Reproduction Science, 130, 187-192. https://doi.org/10.1016/j.anireprosci.2012.01.014

[16] Palacios, C. and Abecia, J.A. (2015) Meteorological Variables Affect Fertility Rate after Intrauterine Artificial Insemination in Sheep in a Seasonal-Dependent Manner: A 7-Year Study. International Journal of Biometeorology, 59, 585-592. https://doi.org/10.1007/s00484-014-0872-y

[17] Abecia, J.A., Arrébola, F., Macías, A., Laviña, A., González-Casquet, O., Benítez, F. and Palacios, C. (2016) Temperature and Rainfall Are Related to Fertility Rate after Spring Artificial Insemination in Small Ruminants. International Journal of Biometeorology, 60, 1603-1609. https://doi.org/10.1007/s00484-016-1150-y

[18] Valentim, R., Rodrigues, I., Montenegro, T., Sacoto, S. and Azevedo, J. (2016) Reproduction Management in Sheep and Goat. 5. Breeding Activity Control in Small Ruminants-Hormonal Methods. Agrotec, 18, 25-28.

https://www.researchgate.net/publication/282327460_Maneio_reprodutivo_em_ovi nos_e_caprinos_4_Controlo_da_atividade_reprodutiva_em_pequenos_ruminantes 
-__metodos_naturais

[19] Romano, J.E., Alkar, A. and Amstalden, M. (2017) Onset of Luteolytic Action of Exogenous Prostaglandin $\mathrm{F}_{2}$ during Estrous Cycle in Goats. Theriogenology, 92, 45-50. https://doi.org/10.1016/j.theriogenology.2016.12.019

[20] Tsakmakidis, I.A. (2010) Ram Semen Evaluation: Development and Efficiency of Modern Techniques. Small Ruminant Research, 92, 126-130. https://doi.org/10.1016/j.smallrumres.2010.04.017

[21] Banday, M.N., Lone, F.A., Rasool, F., Rashid, M. and Shikari, A. (2017) Use of Antioxidants Reduce Lipid Peroxidation and Improve Quality of Crossbred Ram Sperm during Its Cryopreservation. Cryobiology, 74, 25-30. https://doi.org/10.1016/j.cryobiol.2016.12.008

[22] Konyali, C., Tomas, C., Blanch, E., Gomez, E.A., Graham, J.K. and Mocé, E. (2013) Optimizing Conditions for Treating Goat Semen with Cholesterol-Loaded Cyclodextrins Prior to Freezing to Improve Cryosurvival. Cryobiology, 67, 124-131. https://doi.org/10.1016/j.cryobiol.2013.06.001

[23] Russel, A.J.F., Doney, J.M. and Gunn, R.G. (1969) Subjective Assessment of Fat in Live Sheep. The Journal of Agricultural Science, 72, 451-454. https://doi.org/10.1017/S0021859600024874

[24] Correia, T.M.M.A.A. (1996) Study of Churra Galega Bragançana Ewes Seasonality. [Contributo para o Estudo da Sazonalidade Reprodutiva das Ovelhas da Raça Churra Galega Bragançana.] MSc Thesis, CIHEAM-IAMZ, Zaragoza.

[25] Kershaw, C.M., Khalid, M., McGowan, M.R., Ingram, K., Leethongdee, S., Wax, G. and Scaramuzzi, R.J. (2005) The Anatomy of the Sheep Cervix and Its Influence on the Transcervical Passage of an Inseminating Pipette into the Uterine Lumen. Theriogenology, 64, 1225-1235. https://doi.org/10.1016/j.theriogenology.2005.02.017

[26] Steel, R.G.D. and Torrie, J.H. (1980) Principles and Procedures of Statistics. 2nd Edition, McGraw-Hill Company, New York.

[27] Dunn, O.J. (1961) Multiple Comparisons among Means. Journal of the American Statistical Association, 56, 52-64. https://doi.org/10.1080/01621459.1961.10482090

[28] Snedecor, G.W. and Cochran, W.G. (1980) Statistical Methods. 7th Edition, Iowa State University Press, Ames.

[29] SAS Institute Inc. (2009) SAS 9.2 Stored Processes: Developer's Guide. SAS Institute Inc., Cary. https://support.sas.com/documentation/cdl/en/stpug/61271/PDF/default/stpug.pdf

[30] O’Brein, A. (2002) Flushing the Ewe Flock: Is It Beneficial? In: Animal Science FactSheets, Ministry of Agriculture and Food, Ontario. http://www.omafra.gov.on.ca/english/livestock/sheep/facts/02-055.htm

[31] Scaramuzzi, R.J. and Martin, G.B. (2008) The Importance of Interactions among Nutrition, Seasonality and Socio-Sexual Factors in the Development of Hormone-Free Methods for Controlling Fertility. Reproduction in Domestic Animals, 43, 129-136. https://doi.org/10.1111/j.1439-0531.2008.01152.x

[32] Karikari, P.K. and Blasu, E.Y. (2009) Influence of Nutritional Flushing Prior to Mating on the Performance of West African Dwarf Goats Mated in the Rainy Season. Pakistan Journal of Nutrition, 8, 1068-1073. https://doi.org/10.3923/pjn.2009.1068.1073

[33] Steyn, J.J. (2003) Application of Artificial Insemination (AI) on Commercial Sheep 
and Goat Production. In: Proceeding Simpósio Internacional sobre Caprinos e Ovinos de Corte, 2. Simpósio Internacional sobre Agronegócio da Caprinocultura Leiteira, EMEPA-DA, João Pessoa, 367-379.

[34] Al-Azraqi, A.A. (2007) Effect of Fasting on Luteal Function, Leptin and Steroids Concentration during Oestrous Cycle of the Goat in Natural Photo-Status. Animal Reproduction Science, 98, 343-349. https://doi.org/10.1016/j.anireprosci.2006.05.002

[35] Dobson, H., Fergani, C., Routly, J.E. and Smith, R.F. (2012) Effects of Stress on Reproduction in Ewes. Animal Reproduction Science, 130, 135-140. https://doi.org/10.1016/j.anireprosci.2012.01.006

[36] Álvaro, A.C.N. (2014) Post-Partum Physiology Anestrus in Churra Galega Bragançana Ewes Lambed in Fall. [Anestro Fisiológico Pós-parto em Ovelhas Churras Galegas Bragançanas Paridas no Outono.] MSc. Thesis, Polytechnic Institute of Bragança, Braganza.

https://bibliotecadigital.ipb.pt/bitstream/10198/11429/1/Armindo\%20\%C3\%81lvaro .pdf

[37] Silva, T.P.D., Torreão, J.N.C., Marques, C.A.T., Araújo, M.J., Bezerra, L.R., Dhanasekaran, K.D. and Sejian, V. (2016) Effect of Multiple Stress Factors (Thermal, Nutritional and Pregnancy Type) on Adaptive Capability of Native Ewes under Semi-Arid Environment. Journal of Thermal Biology, 59, 39-46.

https://doi.org/10.1016/j.jtherbio.2016.05.001

[38] Ustuner, B., Günay, V., Nur, Z. and Ustuner, H. (2007) Effects of Long and Short Term Progestagen Treatements Combined with PMSG on Oestrus Synchronization and Fertility in Awassi Ewes during the Breeding Season. Acta Veterinaria Brunensis, 76, 391-397. https://doi.org/10.2754/avb200776030391

[39] Freitas, V.J.F. and Rubianes, E. (2004) Female Preparation. Estrus Detection and Ovulation Control. [Preparación de las Hembras. Detección e Control del Estro y de la Ovulación.] In: Aisen, E.G., Ed., Sheep and Goat Reproduction [Reproducción Ovina y Caprina], Chapter 7, Intermédica Editora, São Paulo, 87-98.

[40] Romano, J.E. (1996) Comparison of Fluorgestone and Medroxyprogesterone Intravaginal Pessaries for Estrus Synchronization in Dairy Goats. Small Ruminant Research, 22, 219-223. https://doi.org/10.1016/S0921-4488(96)00893-0

[41] Leyva, V., Buckrell, B.C. and Walton, J.S. (1998) Regulation of Follicular Activity and Ovulation in Ewes by Exogenous Progestogen. Theriogenology, 50, 395-416. https://doi.org/10.1016/S0093-691X(98)00148-4

[42] Ungerfeld, R. and Rubianes, E. (2002) Short Term Primings with Different Progestogen Intravaginal Devices (MAP, FGA and CIDR) for eCG-Estrous Induction in Anestrus Ewes. Small Ruminant Research, 46, 63-66. https://doi.org/10.1016/S0921-4488(02)00105-0

[43] Zeleke, M., Greyling, J.P.C., Schwalbach, L.M.J., Muller, T. and Erasmus, J.A. (2005) Effect of Progestagen and PMSG on Oestrous Synchronization and Fertility in Dorper Ewes during the Transition Period. Small Ruminant Research, 56, 47-53. https://doi.org/10.1016/j.smallrumres.2003.12.006

[44] Mateus, O.J.P. (2014) Breeding Control in Awassi x Sarda Ewes. [Controlo Reprodutivo em Ovelhas Awassi x Sarda.] MSc Thesis, Polytechnic Institute of Bragança, Braganza.

https://bibliotecadigital.ipb.pt/bitstream/10198/11754/1/Tese\%20\%C3\%93scar\%20 \%28Final\%C3\%ADssima\%29.pdf 
[45] Afonso, F.M.T. (2015) Advance of the Breeding Season in Churra Galega Bragançana Ewes. [Antecipação da Estação Reprodutiva em Ovelhas da Raça Churra Galega Bragança.] MSc Thesis, Polytechnic Institute of Bragança, Braganza. (In Press)

[46] Dendena, M.W. (2017) Reproduction Activity Control in Churra Galega Bragançana Ewes. [Controlo da Actividade Reprodutiva e Inseminação Artificial em Ovelhas da Raça Churra Galega Bragançana.] MSc Thesis, Polytechnic Institute of Bragança, Braganza.

https://bibliotecadigital.ipb.pt/bitstream/10198/14178/1/FINAL.pdf

[47] Letelier, C.A., Contreras-Solis, I., García-Fernández, R.A., Sánchez, M.A., García-Palencia, P., Sánchez, B., Ariznavarreta, C., Tresguerres, J.A.F., Flores, J.M. and Gonzalez-Bulnes, A. (2011) Effects of Oestrus Induction with Progestagens or Prostaglandin Analogues on Ovarian and Pituitary Function in Sheep. Animal Reproduction Science, 126, 61-69. https://doi.org/10.1016/j.anireprosci.2011.04.012

[48] Kukovics, S., Gyökér, S., Németh, T. and Gergátz, E. (2011) Artificial Insemination of Sheep-Possibilities, Realities and Techniques at the Farm Level. In: Manafi, M., Ed., Veterinary Medicine and Science, Chapter 3, InTech, Rijeka, 27-50. https://doi.org/10.5772/16642

[49] Valentim, R., Fernandes, M., Azevedo, J., Mendonça, A., Almeida, J., Velasco, H., Simões, J., Fontes, P., Maurício, R., Cardoso, M. and Correia, T. (2009) Advance of the Breeding Season in Churra Galega Bragançana Ewes. Artificial Insemination. [Anticipación de la Estación Reproductiva en Ovejas de la Raza Churra Galega Bragançana. Inseminación Artificial.] Proceedings 34 Congreso Nacional de la Sociedad Española de Ovinotecnia y Caprinotecnia, Barbastro, 403-407. http://seoc.eu/es/2009-barbastro/

[50] Donovan, A., Hanrahan, J.P., Lally, T., Boland, M.P., Lonergan, G.P. and O’Neil, D.J. (2001) AI for Sheep using Frozen-Thawed Semen. ARMIS 4047 Project Report, Under the Research Stimulus Fund; OPARDF Measure 5b.

https://www.researchgate.net/publication/242167475_AI_for_sheep_using_frozen-t hawed_semen

[51] Donovan, A., Hanrahan, J.P., Kummen, E., Duffy, P. and Boland, M.P. (2004) Fertility in the Ewe Following Cervical Insemination with Fresh or Frozen-Thawed Semen at a Natural or Synchronised Oestrus. Animal Reproduction Science, 84, 359-368. https://doi.org/10.1016/j.anireprosci.2003.12.014

[52] Ax, R.L., Dally, M.R., Didion, B.A., Lenz, R.W., Love, C.C., Varner, D.D., Hafez, B. and Bellin, M.E. (2004) Artificial Insemination [Inseminação Artificial]. In: Hafez, E.S.E. and Hafez, B., Eds., Animal Reproduction [Reprodução Animal], 7th Edition, Manole Editor, São Paulo, 381-394.

[53] Cognié, Y. (1988) Nouvelles Méthodes Utilisées pour Améliorer les Performances de Reproduction chez les Ovins. INRA Productions Animales, 1, 83-92. http://prodinra.inra.fr/record/141987

[54] Omontese, B.O., Rekwot, P.I., Ate, I.U., Ayo, J.O., Kawu, M.U., Rwuaan, J.S., Nwannenna, A.I., Mustapha, R.A. and Bello, A.A. (2016) An Update on Oestrus Synchronisation of Goats in Nigeria. Asian Pacific Journal of Reproduction, 5, 96-101. https://doi.org/10.1016/j.apjr.2016.01.002

[55] Aral, F., Temamoğullari, F. and Aral, S.S. (2011) Mechanical and Pharmacologic Applications of Artificial Insemination in Ewes. In: Manafi, M., Ed., Veterinary Medicine and Science, Chapter 14, InTech, Rijeka, 243-254. https://doi.org/10.5772/16564 
[56] Paulenz, H., Söderquist, L., Pérez-Pé, R. and Berger, K.A. (2002) Effect of Different Extenders and Storage Temperature on Sperm Viability of Liquid Ram Semen. Theriogenology, 57, 823-836. https://doi.org/10.1016/S0093-691X(01)00683-5

[57] O’Hara, L., Hanrahan, J.P., Richardson, L., Donovan, A., Fair, S., Vans, A.C.O. and Lonergan, O. (2010) Effect of Storage Duration, Storage Temperature, and Diluent on the Viability and Fertility of Fresh Ram Sperm. Theriogenology, 73, 541-549. https://doi.org/10.1016/j.theriogenology.2009.10.009

[58] Salamon, S. and Maxwell, W.M.C. (2000) Storage of Ram Semen. Animal Reproduction Science, 62, 77-111. https://doi.org/10.1016/S0378-4320(00)00155-X

[59] O’Meara, C.M., Donovan, A., Hanrahan, J.P., Duffy, P., Fair, S., Evans, A.C.O. and Lonergan, P. (2007) Resuspending Ram Spermatozoa in Seminal Plasma after Cryopreservation Does not Improve Pregnancy Rate in Cervically Inseminated Ewes. Theriogenology, 67, 1262-1268.

https://doi.org/10.1016/j.theriogenology.2007.01.012

[60] Bernardini, A., Hozbor, F., Sanchez, E., Fornés, M.W., Alberio, R.H. and Cesari, A. (2011) Conserved Ram Seminal Plasma Proteins Bind to the Sperm Membrane and Repair Cryopreservation Damage. Theriogenology, 76, 436-447.

https://doi.org/10.1016/j.theriogenology.2011.02.020

[61] Amidi, F., Pazhohan, Maryam, A., Nashtaei, S., Khodarahmian, M. and Nekoonam, S. (2016) The Role of Antioxidants in Sperm Freezing: A Review. Cell Tissue Bank, 17, 745-756. https://doi.org/10.1007/s10561-016-9566-5

[62] Sieme, H., Oldenhof, H. and Wolkers, W.F. (2016) Mode of Action of Cryoprotectants for Sperm Preservation. Animal Reproduction Science, 169, 2-5. https://doi.org/10.1016/j.anireprosci.2016.02.004

[63] Arando, A., Gonzalez, A., Delgado, J.V., Arrebola, F.A. and Perez-Marín, C.C. (2017) Storage Temperature and Sucrose Concentrations Affect Ram Sperm Quality after Vitrification. Animal Reproduction Science, 181, 175-185. https://doi.org/10.1016/j.anireprosci.2017.04.008

[64] Santolaria, P., Palacin, I. and Yaniz, J. (2011) Management Factors Affecting Fertility in Sheep. Chapter 11, InTech, Rijeka, 167-190. https://doi.org/10.5772/18013

[65] Kaabi, M., Alvarez, M., Anel, E., Chamorro, C.A., Boixo, J.C., de Paz, P. and Anel, L. (2006) Influence of Breed and Age on Morphometry and Depth of Inseminating Catheter Penetration in the Ewe Cervix: A Postmortem Study. Theriogenology, 66, 1876-1883. https://doi.org/10.1016/j.theriogenology.2006.04.039

[66] Fonseca, J.F., Cruz, R.C., Pinto, P.H.N. and Facó, O. (2010) Artificial Insemination in Sheep and Goat. [Inseminação Artificial em Ovinos e Caprinos.] Proceedings of the I Workshop sobre Ciência Animal na Bahia, BA-UESC, Ilhéus, 1-30. https://ainfo.cnptia.embrapa.br/digital/bitstream/item/102769/1/AAC-Inseminacao -artificial.pdf 